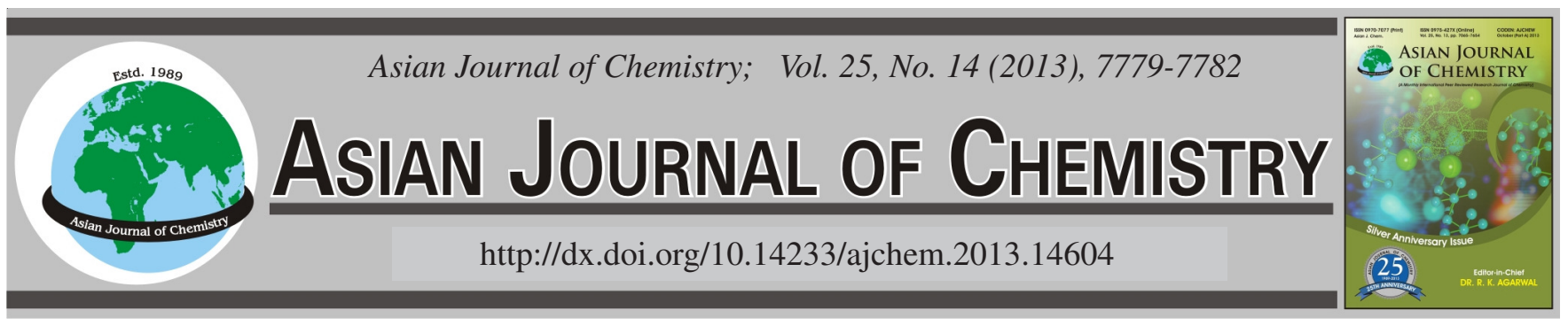

\title{
Synthesis and Spectroscopic Studies of Ru(II) Complexes of 1,2,4-Triazoles, 1,2,4-Triazines and Pyrimidine Derivatives
}

Abdullah M. Asiri, A.O. Baghlaf, R.M. Abdel-Rahman, Salman A. Khan ${ }^{*}$ and M. Ishaq

Department of Chemistry, Faculty of Science, King Abdulaziz University, P.O. Box 80203, Jeddah-21589, Saudi Arabia

*Corresponding author: Tel: +966 2 0598337050; E-mail: sahmad_phd@yahoo.co.in

(Received: 21 September 2012;

Accepted: 15 July 2013)

AJC-13807

Treatment of the dichlorodicarbonyl ruthenium(II) $\left[\mathrm{Ru}(\mathrm{CO})_{2} \mathrm{Cl}_{2}\right]_{\mathrm{n}}$ with bidentate 1,2,4-triazoles, 1,2,4-triazines and pyrimidine derivatives in refluxing ethanol or in THF yielded stable, octahedral yellow or pale-yellow solids. All the complexes have been characterized by IR, ${ }^{1} \mathrm{H}$ NMR spectroscopy and elemental analyses.

Key Words: Ruthenium(II), Triazoles, Triazines, Pyrimidine.

\section{INTRODUCTION}

Coordination modes of metal complexes with organic ligands with heteroatom $\mathrm{N}, \mathrm{S}$ or $\mathrm{O}$ are well known. The usefulness of metal complexes with such ligands exhibit remarkable biological activity against certain microbes, viruses and tumors $^{1-3}$. The presence of heteroatom in such ligands play a key role when coordinated with transition metal atom for example 1,2,4-triazine derivative of $\mathrm{Pd}(\mathrm{II})$ and $\mathrm{Pt}(\mathrm{II})$ show mono-dentate or bidentate behaviour ${ }^{4}$. Similarly derivatives of 1,2,4-triazoles and 1,2,4-tiazine act as bidentate and exhibit tautomerism or ambidentate nature on coordination with metal atom. For example 3-alkyl-4-amino-5-thiol derivative of 1,2,4triazole show a 5-membered ring complex on coordination with $\mathrm{Co}(\mathrm{II})$ or $\mathrm{Ni}(\mathrm{II})^{5}$. We have previously reported that $\mathrm{Ru}(\mathrm{II})$ forms very stable six membered complexes with ligands containing heteroatom $\mathrm{N}, \mathrm{S}$ and $\mathrm{O}$. These heteroatom's act as an electron donor to metal ${ }^{6,7}$. Now we report the preparation of $\mathrm{Ru}(\mathrm{II})$ complexes with 1,2,4-triazoles, 1,2,4-triazines and pyrimidine derivatives (Scheme I-IV). Ruthenium(II) in these complexes acts as an electron acceptor. This enhanced its ability to coordinate with electron donor ligand to yield a stable and electron rich compound of low ionization energy. The complexes (1a), (2a), (3a), (4a), (6a) show their tautomeric nature on coordination with metal $\mathrm{Ru}(\mathrm{II})$ while in complex 5a the ligand acts as an ambidentate nature (Scheme-IV).

The IR spectra of all these complexes show only two metal terminal (Ru-CO) band near $2000 \mathrm{~cm}^{-1}$ and are in cis disposition $^{6,7,9}$. All the ligands form a six membered ring structure around the metal $\mathrm{Ru}(\mathrm{II})$. IR and ${ }^{1} \mathrm{H}$ NMR spectra of complexes are shown in Tables 1 and 2, respectively. The elemental

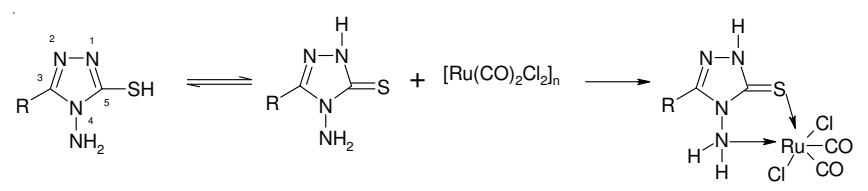

$\mathrm{R}=\mathrm{CH}_{3}(1,1 \mathrm{a}), \mathrm{C}_{6} \mathrm{H}_{5}(2,2 \mathrm{a}), \mathrm{C}_{5} \mathrm{H}_{5} \mathrm{~N}(3,3 \mathrm{a})$

Scheme-I: Complex (1a), (2a), (3a) tautomeric nature of thiol/thione of 3methyl/phenyl/pyridine-4-amino-5-thiol 1,2,4 triazole

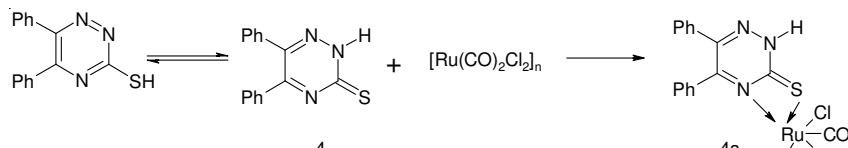

$$
\begin{aligned}
& \text { 4a } \mathrm{Cl}^{\prime} \mathrm{Ru}-\mathrm{CO}
\end{aligned}
$$

Scheme-II: Complex 2a tautomeric nature of 3-thiol-5,6-diphenyl-1,2,4triazine

$$
\text { (Ru(CO) } \left.C_{2}\right]_{n}
$$

Scheme-III: Complex 5a ambidentate nature of 3-hydrazino-5,6-diphenyl1,2,4-triazine

analyses are given in experimental section are consistent with proposed structures and formulations.

\section{EXPERIMENTAL}

The salt $\mathrm{RuCl}_{3} \cdot \mathrm{xH}_{2} \mathrm{O}$ was purchased from FLUKA Inc. and $\left[\mathrm{Ru}(\mathrm{CO})_{2} \mathrm{Cl}_{2}\right]_{\mathrm{n}}$ was prepared by the procedure reported in literature $^{8,9}$. 


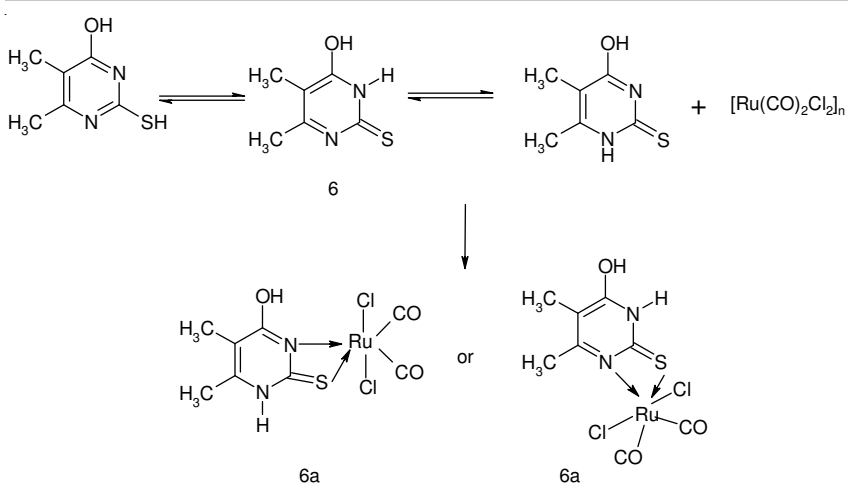

Scheme-IV: Complex 6a tautomeric nature of 4-hydroxy-2-thio/5,6dimethyl pyrimidine

The ligand 3-alkyl-4-amino-5-thiol-1,2,4 triazole and its aryl or pyrimidine derivatives were prepared by method as reported in the literature ${ }^{10}$. While the ligand 3-hydrazino-5,6dipheniyl-1,2,4-triazine was prepared as reported in literature ${ }^{11}$.

Physical measurements: IR spectra were measured on Perkin-Elmer FTIR spectrometer. ${ }^{1} \mathrm{H}$ NMR were recorded on BRUCKER-AVANCE-111 600MHz. Elemental analyses were carried out by the Microanalysis Laboratory of King Abdulaziz University, Jeddah.

\section{Preparation of the compounds}

Typical reaction is described: In a small $100 \mathrm{~mL}$ round bottom 2-necked flask fitted with $\mathrm{N}_{2}$ gas inlet and water condenser was added $\left[\mathrm{Ru}(\mathrm{CO})_{2} \mathrm{Cl}_{2}\right]_{\mathrm{n}}$ and the corresponding ligand of 1,2,4-triazole in (1:1) mole ratio in ethanol or THF $(20 \mathrm{~mL})$. The solution was refluxed for $2 \mathrm{~h}$. The solvent was reduced in volume which on cooling gave a yellow or pale yellow crystallized solid 1a-6a. The complex was washed with pet. ether at $30-40{ }^{\circ} \mathrm{C}$ and dried in vacuum.

TABLE-1

IR SPECTRAL BANDS $\left(\mathrm{cm}^{-1}\right)^{\mathrm{a}}$

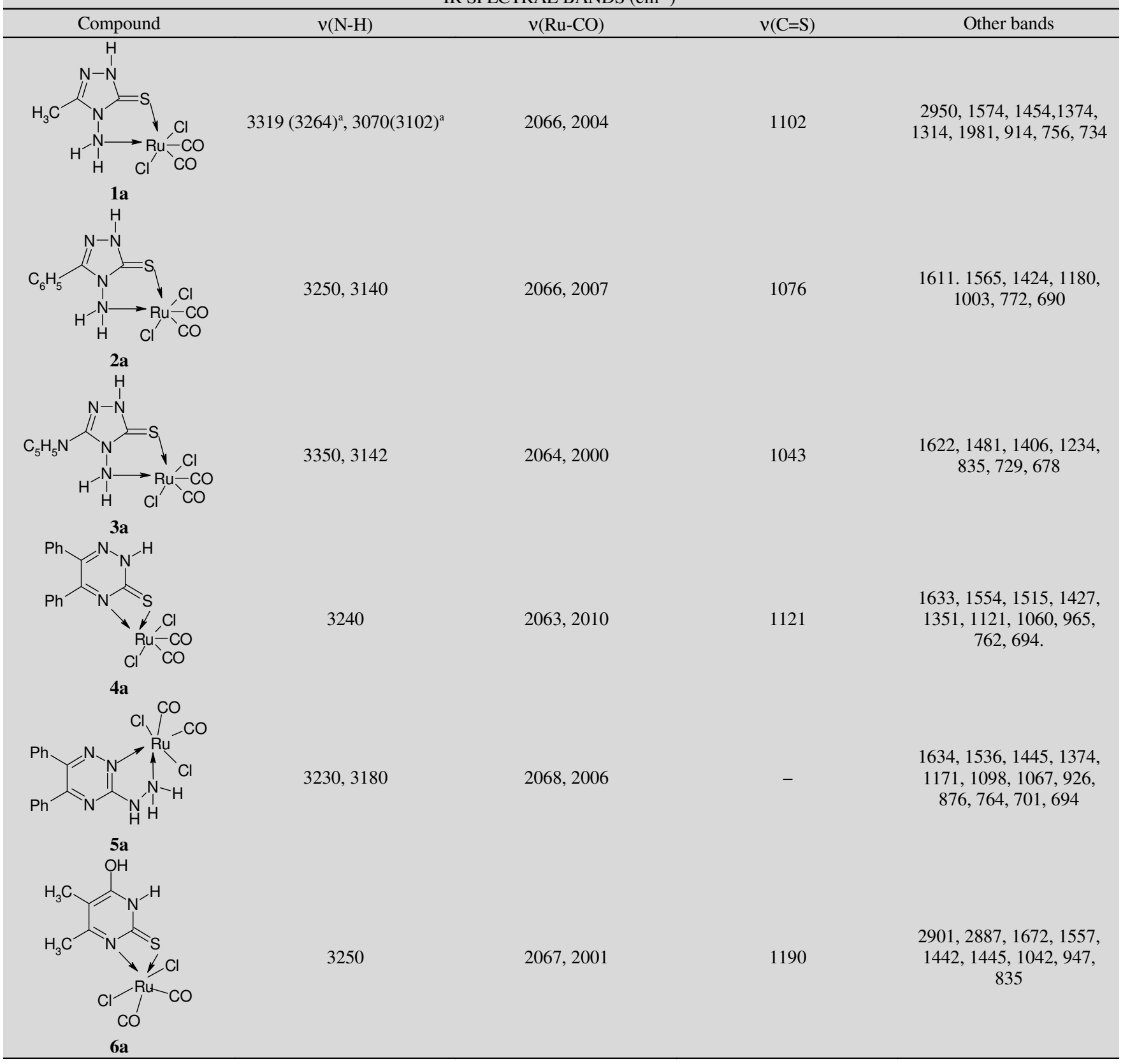




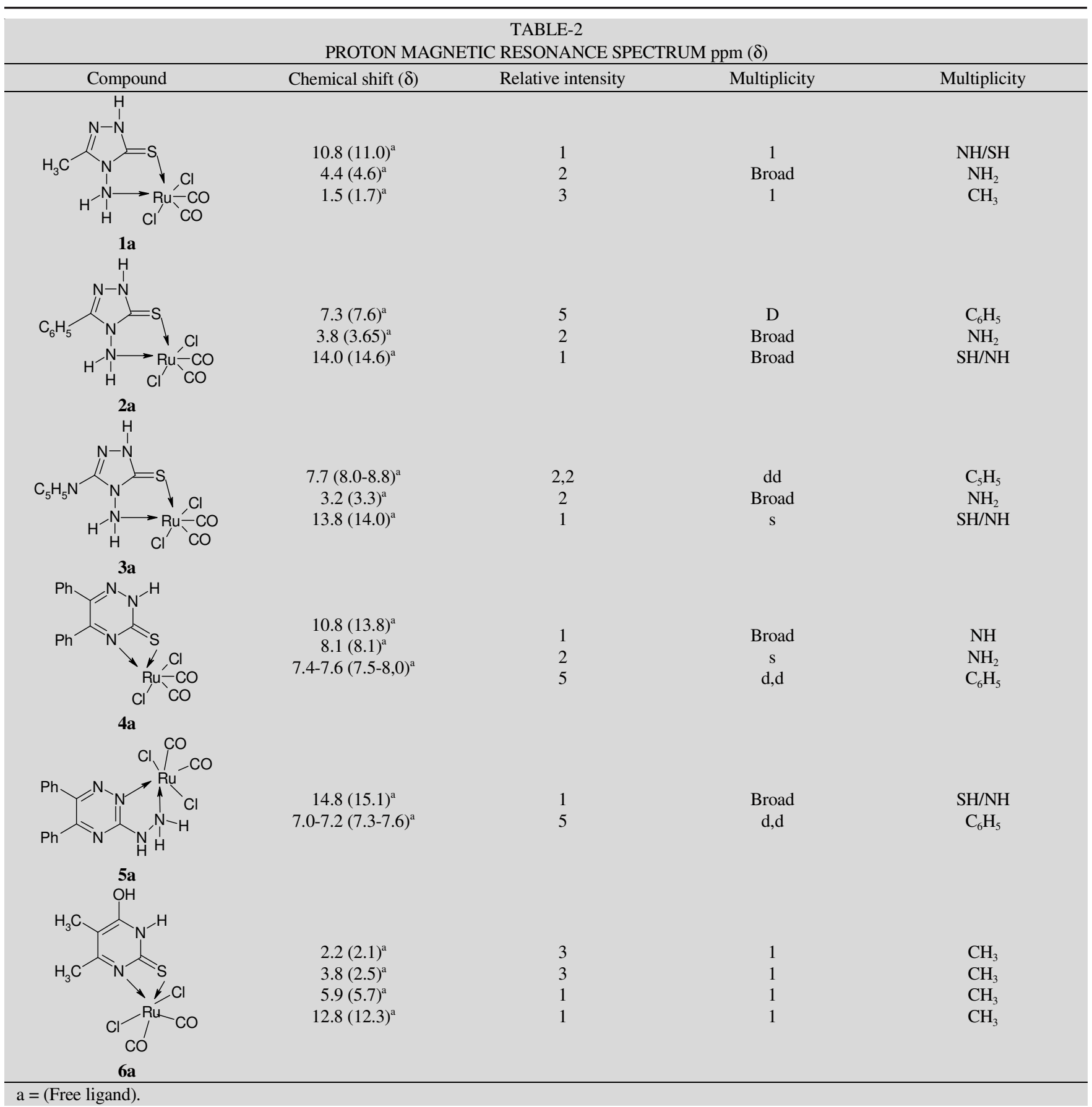

All the complexes shown in Scheme I-IV were prepared according to this general method using $(1: 1)$ mole ratio of the salt $\left[\mathrm{Ru}(\mathrm{CO})_{2} \mathrm{Cl}_{2}\right]_{\mathrm{n}}$ and the corresponding ligand.

Preparation of dichorodicarbonyl-3-methyl-4-amino5-thio-1,2,4-triazole ruthenium (II) (1a): The salt $\left[\mathrm{Ru}(\mathrm{CO})_{2} \mathrm{Cl}_{2}\right]_{\mathrm{n}}(0.2 \mathrm{~g})$ and the ligand $(0.11 \mathrm{~g})$ were refluxed in $20 \mathrm{~mL}$ THF for $1 \mathrm{~h}$. The solution was worked out as described above which gave reddish yellow solid. Anal. calcd. (\%) for $\left[\mathrm{C}_{5} \mathrm{H}_{6} \mathrm{~N}_{4} \mathrm{O}_{2} \mathrm{SCl}_{2}\right] \mathrm{Ru}$ : C, 16.7, H, 1.6, N, 15.6, Found (\%): C, 16.1, H, 1.7, N. 15.2.

Preparation of dichorodicarbonyl-3-phenyl-4-amino5-thio-1,2,4 triazole ruthenium(II) (2a): The salt $\left[\mathrm{Ru}(\mathrm{CO})_{2} \mathrm{Cl}_{2}\right]_{\mathrm{n}}(0.2 \mathrm{~g})$ and the ligand $(0.11 \mathrm{~g})$ were refluxed in $20 \mathrm{~mL}$ THF for $1 \mathrm{~h}$. This gave yellow solid. Anal. calcd. (\%) for $\left[\mathrm{C}_{10} \mathrm{H}_{8} \mathrm{~N}_{4} \mathrm{O}_{2} \mathrm{SCl}_{2}\right] \mathrm{Ru}$ : C, 28.5, H, 1.9, N, 13.3, found (\%): C, 28.1, H, 1.7, N. 13.9.
Preparation of dichorodicarbonyl-3-pyridine-4amino-5-thio-1,2,4 triazole ruthenium(II) (3a): Take the salt $\left[\mathrm{Ru}(\mathrm{CO})_{2} \mathrm{Cl}_{2}\right]_{\mathrm{n}}(0.1 \mathrm{~g}, 0.438 \mathrm{mmol})$ and the ligand $(0.116 \mathrm{~g}$ $0.438 \mathrm{~mm}$ ) in $20 \mathrm{~mL}$ EtOH were refluxed for $1.5 \mathrm{~h}$ and worked as above. This gave light orange solid. Anal. calcd. (\%) for $\left[\mathrm{C}_{9} \mathrm{H}_{8} \mathrm{~N}_{4} \mathrm{O}_{2} \mathrm{SCl}_{2}\right] \mathrm{Ru}: \mathrm{C}, 25.5, \mathrm{H}, 1.8, \mathrm{~N}, 16.5$, found (\%): C, 25.1, H, 1.6, N. 16.1.

Preparation of dichlorodicarbnyl-3-thiol-5,6-diphenyl1,2,4-triazine ruthenium (II) (4a): The salt $\left[\mathrm{Ru}(\mathrm{CO})_{2} \mathrm{Cl}_{2}\right]_{\mathrm{n}}$ and the ligand were refluxed in $20 \mathrm{~mL}$ THF for $1 \mathrm{~h}$. The solution was worked out as described above and it gave yellow solid. Anal. calcd. (\%) for $\left[\mathrm{C}_{17} \mathrm{H}_{10} \mathrm{~N}_{3} \mathrm{O}_{2} \mathrm{SCl}_{2}\right] \mathrm{Ru}$ : C, 41.4, H, 2.0, N, 8.5, found (\%): C, 42.0, H, 2.2, N. 8.3.

Preparation of dichlorodicarbnyl-3-hydrazino-5,6diphenyl-1,2,4-triazine ruthenium (II) (5a): The salt $\left[\mathrm{Ru}(\mathrm{CO})_{2} \mathrm{Cl}_{2}\right]_{\mathrm{n}}$ and the ligand in (1:1) mole ratio were refluxed 
in $20 \mathrm{~mL}$ EtOH for $1.5 \mathrm{~h}$. Which gave yellow solid. Anal. calcd. $(\%)$ for $\left[\mathrm{C}_{17} \mathrm{H}_{13} \mathrm{~N}_{5} \mathrm{O}_{2} \mathrm{Cl}_{2}\right] \mathrm{Ru}: \mathrm{C}, 41.5, \mathrm{H}, 2.6, \mathrm{~N}, 14.2$, Found (\%): C, 41.9, H, 3.0, N. 14.4.

Preparation of dichlorodicarbnyl-2-mercapto-4hydroxy 5,6-dimethyl pyrimidin ruthenium (II) (6a): The salt $\left[\mathrm{Ru}(\mathrm{CO})_{2} \mathrm{Cl}_{2}\right]_{\mathrm{n}}(0.15 \mathrm{~g})$ and the ligand $(0.1 \mathrm{~g})$ were refluxed in $20 \mathrm{~mL}$ THF for $2 \mathrm{~h}$. The solution was reduced in vol. and addition of pet.ether $30-40{ }^{\circ} \mathrm{C}$ gave yellow solid in good yield. Anal. calcd. (\%) for $\left[\mathrm{C}_{8} \mathrm{H}_{8} \mathrm{~N}_{2} \mathrm{O}_{2} \mathrm{SCl}_{2}\right] \mathrm{Ru}: \mathrm{C}, 26.0, \mathrm{H}, 2.1, \mathrm{~N}$, 7.6, found (\%): C, 26.4, H, 2.0, N. 8.0.

\section{RESULTS AND DISCUSSION}

The structure of complex (1a) dichlorodicarbonyl-3methyl-4-amino-5-thione ruthenium (II) as shown in SchemeI and other structures (2a), (3a), (4a) and (6a) show $\mathrm{S}=\mathrm{C}-\mathrm{N}-\mathrm{N}$ unit which acts as bidentate to the metal Ru(II) through (N) amine and (S) thione to give very stable crystallized solid six membered ring with tautomeric structure while complex (5a) may be represented as having ambidentate character. On comparing the IR spectra of these complexes with their free ligands clearly show that there is $v(\mathrm{~N}-\mathrm{H})$ asym and sym symetrical stretching frequencies in the region of $3200-3100 \mathrm{~cm}^{-1}$ and a band $\delta \mathrm{NH}$ near $1600 \mathrm{~cm}^{-1}$ while $v(\mathrm{C}-\mathrm{H})$ for $\mathrm{CH}_{3}, \mathrm{C}_{6} \mathrm{H}_{5}$ and $\mathrm{C}_{5} \mathrm{H}_{5}-\mathrm{N}$ group are at $2900-2800 \mathrm{~cm}^{-1}$. A band for $\mathrm{v}(\mathrm{C}=\mathrm{S})$ around 1100-1130. All these complexes show very distinct two sharp bands around 2070 and $2004 \mathrm{~cm}^{-1}$ which are metal terminal-carbonyl (Ru-CO) and are in cis disposition ${ }^{6,79}$. These bands in the salt $\left[\mathrm{Ru}(\mathrm{CO})_{2} \mathrm{Cl}_{2}\right]_{\mathrm{n}}$ are at 2145,2075 and 2020 $\mathrm{cm}^{-1} 8,9 .{ }^{1} \mathrm{H}$ NMR spectrum of complex (1a) shows a single band at $1.7 \delta\left(\mathrm{NH}_{2}\right)$ and a single band at $3.8 \delta(\mathrm{N}-\mathrm{H})$ which may be due to tautomeric NH/SH protons of phenyl groups around 7.0-7.5 $\delta$ while the (5a) shows protons of hydrazine $\left(\mathrm{NH}-\mathrm{NH}_{2}\right)$ very clearly, see Table- 2 . It is note worthy that proton magnetic resonance of all the complexes show a slight down field compared to free ligand as a result of coordination to the metal $\mathrm{Ru}(\mathrm{II})$ ion which acts as electron acceptor from the ligand to the metal $\mathrm{Ru}(\mathrm{II})$ that causes down field shift in all the complexes.

${ }^{1} \mathrm{H}$ NMR spectra of all complexes show a slight down field shift that may be due to the coordination between ligands and the electron deficient metal $\mathrm{Ru}(\mathrm{II})$.

\section{ACKNOWLEDGEMENTS}

The authors are thankful to Department of Chemistry, King Abdulaziz University, to provide the research facilities and also thanks to under graduate students Mr. Ibrahim M. Al-Shawoosh and Mr. Emad O. Al-Busysi for some research support.

\section{REFERENCES}

1. S. Padhye and G.B. Kaufman, Coord. Chem. Rev., 63, 127 (1985).

2. A.M. Asiri and S.A. Khan, Molecules, 15, 4784 (2010).

3. E. Bermego, R. Carballo, A. Castimeiras, R. Domingues, C.M. Mossmer, J. Strahle and D.X. West, Polyhedron, 18, 3695 (1999).

4. M. Ghassemzadeh, M.M. Aghayan and B. Neumuller, Inorg. Chim. Acta, 358, 2057 (2005).

5. C.M. Menzies and P.J. Squattrito, Inorg. Chim. Acta, 314, 194 (2001).

6. A.O. Baghlaf, M. Ishaq and A.K.A. Rashed, Polyhedron, 6, 837 (1987).

7. A.O. Baghlaf, M. Ishaq, S.A. Rahman, A.B. Al-Tahir, A. Zaidan and R.A. Kabli, Polyhedron, 7, 219 (1988).

8. R. Colton and R.H. Farthing, Aust. J. Chem., 20, 1283 (1997).

9. M.J. Cleare and W.P. Griffith, J. Chem. Soc. (A), 372 (1969).

10. R.M. Abdel-Rahman, Pharmazie, 56, 18 (2001).

11. C. Ma, G. Tian and R. Zhang, Inorg. Chem. Commun., 9, 882 (2006). 